\title{
Symptoms, symptom relief and support in COVID-19 patients dying in hospitals during the first pandemic wave
}

Lisa Martinsson 1* (D), Jonas Bergström², Christel Hedman ${ }^{3,4}$, Peter Strang ${ }^{3,5}$ and Staffan Lundströmm

\begin{abstract}
Background: At the time of the first wave of the COVID-19 pandemic in Sweden, little was known about how effective our regular end-of-life care strategies would be for patients dying from COVID-19 in hospitals. The aim of the study was to describe and evaluate end-of-life care for patients dying from COVID-19 in hospitals in Sweden up until up until 12 November 2020.
\end{abstract}

Methods: Data were collected from the Swedish Register of Palliative Care. Hospital deaths during 2020 for patients with COVID-19 were included and compared to a reference cohort of hospital patients who died during 2019. Logistic regression was used to compare the groups and to control for impact of sex, age and a diagnosis of dementia.

Results: The COVID-19 group (1476 individuals) had a lower proportion of women and was older compared to the reference cohort (13,158 individuals), 81.8 versus 80.6 years $(p<.001)$. Breathlessness was more commonly reported in the COVID-19 group compared to the reference cohort ( $72 \%$ vs $43 \%, p<.001)$. Furthermore, anxiety and delirium were more commonly and respiratory secretions, nausea and pain were less commonly reported during the last week in life in the COVID-19 group ( $p<.001$ for all five symptoms). When present, complete relief of anxiety ( $p=.021)$, pain $(p=.025)$ and respiratory secretions ( $p=.037)$ was more often achieved in the COVID-19 group. In the COVID-19 group, 57\% had someone present at the time of death compared to $77 \%$ in the reference cohort $(p<.001)$.

Conclusions: The standard medical strategies for symptom relief and end-of-life care in hospitals seemed to be acceptable. Symptoms in COVID-19 deaths in hospitals were relieved as much as or even to a higher degree than in hospitals in 2019. Importantly, though, as a result of closing the hospitals to relatives and visitors, patients dying from COVID-19 more frequently died alone, and healthcare providers were not able to substitute for absent relatives.

Keywords: COVID-19, Pandemic, Palliative care, End-of-life care, Hospitals, Dementia

\footnotetext{
* Correspondence: lisa.martinsson@umu.se

'Department of Radiation Sciences, Umeå University, SE-90187 Umeå,

Sweden

Full list of author information is available at the end of the article
}

(c) The Author(s). 2021 Open Access This article is licensed under a Creative Commons Attribution 4.0 International License, which permits use, sharing, adaptation, distribution and reproduction in any medium or format, as long as you give appropriate credit to the original author(s) and the source, provide a link to the Creative Commons licence, and indicate if changes were made. The images or other third party material in this article are included in the article's Creative Commons licence, unless indicated otherwise in a credit line to the material. If material is not included in the article's Creative Commons licence and your intended use is not permitted by statutory regulation or exceeds the permitted use, you will need to obtain permission directly from the copyright holder. To view a copy of this licence, visit http://creativecommons.org/licenses/by/4.0/. The Creative Commons Public Domain Dedication waiver (http://creativecommons.org/publicdomain/zero/1.0/) applies to the data made available in this article, unless otherwise stated in a credit line to the data. 


\section{Introduction}

The first cases of a new coronavirus disease, COVID-19, were reported in December 2019 in China [1, 2]. On 21 February 2020, nine European countries had reported a total of 47 cases [3]. COVID-19 is a new virus with new symptoms and trajectories $[2,4]$. The narratives received from around the world picturing acute hospitals struggling with COVID-19 patients [5] caused the healthcare services to plan how to meet this pandemic on all different levels. It forced hospitals and caregivers to find new ways and treatments to provide the best possible care for these patients.

In the beginning of the pandemic palliative care guidelines were written, both in Sweden and worldwide, on how to provide patients dying from COVID-19 with good supportive care and how to alleviate symptoms [6$8]$, although little was known about what kind of problems to expect. At first glance, some symptoms may seem obvious in a lethal viral infection affecting the lungs, like breathlessness and respiratory secretions. However, other symptoms such as nausea, delirium, pain and anxiety are frequently seen near death in other conditions. It was not known how common those symptoms would be in hospitalised patients dying from COVID-19 or how well such symptoms could be alleviated. Little was known about the effect of our regular end-of-life care strategies, including drugs for symptom management in hospitals, for patients dying from COVID-19. However, emerging data show that the presentation of COVID-19 is diverse in both severity and symptoms.

The first wave in Sweden and worldwide was most intense during the spring 2020, with a new wave starting during the autumn and in Sweden in November 2020 [9, 10]. Early during the first wave, it was apparent that the initial global lack of personal protective gear [11] made it more difficult for healthcare professionals to be present bedside to the same extent that they normally are. Furthermore, there were restrictions on family visitation up until the time when the patient was immediately dying. This made it more difficult to provide optimal end-of-life care [5, 12-14]. The restrictions on family visitation were aimed at minimising spread of the disease but were also related to a shortage of personal protective gear.

Swedish healthcare is largely tax funded, and everyone should have equal access to healthcare services. The central government establishes principles and guidelines and sets the political agenda for health and medical care, but the actual care is decentralised to 21 regional councils that are expected to provide residents with goodquality health and medical care.

Nursing home residents, including many people with dementia, have been heavily affected by the pandemic. During the spring 2020 when deaths rates in nursing homes from COVID-19 were very high, there was a debate regarding old and fragile people with multiple diseases not always being offered hospital care when appropriate. Poloni et al. described in July 2020 that the combination of dementia and COVID-19 is associated with delirium [15] and with more unspecific and less prominent symptoms [16]. These facts indicate that people with dementia are a group of patients suffering from COVID-19 who require special attention, including in hospital settings.

\section{Aim}

The aim was to study symptoms, symptom relief and support to patients dying from COVID-19 in hospitals, in comparison to a reference population (hospital deaths in 2019). Focus was on the occurrence and relief of symptoms during the last week of life, prescription of pro re nata (PRN) drugs against symptoms, administration of parenteral fluids during the last day, and the proportion of patients dying alone. A further aim was to control these factors for sex, age and a diagnosis of dementia, by the aid of logistic regression models.

\section{Methods}

We used data from the Swedish Register of Palliative Care (SRPC), a national quality register focusing on quality of care during the last week in life, regardless of diagnosis, place of residence and level of care. Data are reported to the SRPC from healthcare staff after death of a patient, using a validated end-of-life questionnaire (ELQ) $[17,18]$. Each year, around $60 \%$ of all deaths in Sweden are reported to the SRPC. The SRPC registers symptom data on breathlessness, anxiety, delirium, respiratory secretions, nausea, and pain. If the patient was indicated to have a symptom, symptom relieve was registered as complete, partial, or no relieve $[17,18]$. The process that the SRPC uses for data collection has previously been described by our group [12].

The COVID-19 group consisted of all adults deceased in hospitals from the first reported death in March 2020 up until 12 November 2020 and reported to the SRPC as having a clinical COVID-19 infection. Both laboratoryverified and non-verified cases were included, mostly because laboratory testing was not possible in all cases in the beginning of the pandemic. The options regarding COVID-19 infection were "no infection", "yes ongoing infection", "yes suspected ongoing infection", "earlier infection" and "unknown". Those included in the COVID19 group were: "yes ongoing infection", "yes suspected ongoing infection". All adults ( $\geq 18$ years of age) deceased in hospitals between January 1st to December 31st 2019 and reported to the SRPC formed the reference cohort. Since most items in the SRPC used in this study, including symptoms, are not gathered for patients 
reported to have died unexpectedly, these patients were excluded from the analyses in both groups. Patients from all types of hospital wards (infection, geriatrics, internal medicine, surgery, etc.) except specialised palliative care wards (which cannot be distinguished from specialised palliative care wards outside of hospitals in the database) were included. Palliative care units were excluded because the majority of those units are outside hospitals in Sweden. In addition, the care in these units differs from usual hospital care which might affect the results.

As patients with dementia have been shown to present with different symptoms from COVID-19 compared to other patients, we adjusted the results for dementia in addition to sex and age.

\section{Statistical analyses}

The COVID-19 group and the reference cohort were compared using t-test for comparison of means and chi-2 test for comparison of proportions. Logistic regression was used to control for the impact of age and to control for multiple independent variables. The following outcomes measured with the ELQ and collected from the SRPC were compared between the groups: occurrence of breakthrough of six symptoms during the last week of life ("Yes" vs "No") and when present, relief of these six symptoms (breathlessness, anxiety, delirium, respiratory secretions, nausea and pain) during the last week of life ("Completely" vs "Partially" or "Not at all"); human presence at the time of death (close friend(s) and/or relative(s) vs staff or no one; and close friend(s) and/or relative(s) or staff vs no one); whether parenteral fluids/nutrition or enteral-tube feeding were administered during the last 24h ("Yes" vs "No"); and whether PRN opioid against pain and PRN drugs against anxiety, nausea and respiratory secretions had been prescribed ("Yes" vs "No"). All items used in the analyses except age, sex and relief of symptoms when present could be answered with "Don't know" in the ELQ, and these responses were excluded from the corresponding analysis.

Age was categorised into the following groups: 18-64, $65-74,75-84,85-94$ and $\geq 95$ years. In the analyses regarding relief of symptoms when present, only patients who were reported to have had that particular symptom were included. When analysing relief of symptoms when present, age was used as a continuous variable due to there being too few individuals eligible in each age category. Regarding those with dementia, symptom occurrence but not degree of relief of symptoms when present was analysed, because of too few patients having reported symptoms.

The Statistical Package for the Social Sciences (SPSS) version 26.0 (IBM Corp., Armonk, NY, USA) was used.

\section{Results}

\section{Study population}

A total of 10,748 hospital deaths in 2020 had been registered in the SRPC up until data retrieval (not including deaths that were registered as unexpected based on the disease trajectory). Of these, 1476 adult patients died with an ongoing COVID-19 infection according to the staff's clinical assessment and were included in the study, and of these, 1247 were PCR-verified. The other cases were reported to have had a COVID-19 infection based on clinical presentation, out of whom 157 had tested negative, 47 had been tested but no answer was available and 13 had not been tested; for 12 it was unknown or not reported whether they had been tested.

A total of 13,158 adult hospital deaths during 2019 were identified in the SRPC (not including deaths that were registered as unexpected based on the disease trajectory), and these formed the reference cohort.

\section{Comparison between COVID-19 group and reference cohort}

The COVID-19 group had a higher mean age (analysed with $t$ test) and a lower proportion of women (analysed with chi2-test) compared to the reference cohort. The groups did not differ regarding the proportion of patients having dementia reported as a contributing cause of death (analysed with chi2-test) (Table 1).

Breathlessness was more commonly reported in the COVID-19 group compared to the reference cohort (72\% vs $43 \%), x^{2}(\mathrm{df}=1, n=13,004)=406, p<.001$. Furthermore, anxiety $\left(\mathrm{X}^{2} \quad(\mathrm{df}=1, \quad n=11,706)=81.3\right.$, $p<.001)$, and delirium $\left(\mathrm{x}^{2}(\mathrm{df}=1, n=11,231)=31.3\right.$, $p<.001)$ were more commonly, and respiratory secretions $\left(\mathrm{X}^{2}(\mathrm{df}=1, n=13,754)=57.5, p<.001\right)$, nausea $\left(\mathrm{X}^{2}\right.$ $(\mathrm{df}=1, n=11,236)=16.5, p<.001)$ and pain $\left(\mathrm{X}^{2}(\mathrm{df}=1\right.$, $n=13,217)=17.1, p<.001$ ) were less commonly, reported during the last week in life in the COVID-19 group. When present, complete relief of anxiety $\left(\mathrm{x}^{2}(\mathrm{df}=\right.$ $1, n=6686)=5.4, p=.021)$, pain $\left(\mathrm{X}^{2}(\mathrm{df}=1, n=8782)=\right.$ $5.0, p=.025)$ and respiratory secretions $\left(\mathrm{X}^{2}(\mathrm{df}=1, n=\right.$ $7729)=4.4, p=.037)$ was more often reported in the COVID-19 group compared to the reference cohort. The proportion of patients who were completely relieved from breathlessness, delirium and nausea, when these symptoms were present, did not differ between the groups (Table 1).

Having close friend(s) and/or relative(s) present at the time of death $\left(\mathrm{X}^{2}(\mathrm{df}=1, n=14,155)=463, p<.001\right)$, as well as having someone, including staff, present $\left(\chi^{2}(\mathrm{df}=\right.$ $1, n=14,155)=271, p<.001$ ), was less common in the COVID-19 group. Parenteral fluids/nutrition or enteraltube feeding was slightly more often given during the last $24 \mathrm{~h}$ in the COVID-19 group $\left(\mathrm{X}^{2}(\mathrm{df}=1, n=14\right.$, $215)=4.7, p=.031$ ). Both individual prescriptions of 
Table 1 A comparison of patient characteristics between the COVID-19 group and the reference cohort. Analysed with t-test (age) and chi2-test (all other comparisons)

\begin{tabular}{|c|c|c|c|c|}
\hline Characteristics & $\begin{array}{l}\text { COVID-19 } \\
\text { patients }(n=1476)\end{array}$ & $\begin{array}{l}\text { Reference cohort } \\
\text { from } 2019 \\
(n=13,158)\end{array}$ & $x^{2}$ & $P$-value \\
\hline Age in years, mean (range) & $81.8(20-107)$ & $80.6(18-107)$ & $-{ }^{c}$ & $<.001$ \\
\hline Female sex (\%) & $624 / 1476$ (42\%) & $6303 / 13,158(48 \%)$ & 16.85 & $<.001$ \\
\hline Dementia & 103/1476 (7\%) & $828 / 13,158(6 \%)$ & 1.0 & .31 \\
\hline Breathlessness $^{\mathrm{a}}$ & 953/1324 (72\%) & $5007 / 11,680(43 \%)$ & 406 & $<.001$ \\
\hline Complete relief & 286/953 (30\%) & 1428/5007 (29\%) & 0.9 & .35 \\
\hline Anxiety $^{a}$ & $825 / 1189$ (69\%) & $5861 / 10,517(56 \%)$ & 81.3 & $<.001$ \\
\hline Complete relief $^{b}$ & 493/825 (60\%) & $3252 / 5861(56 \%)$ & 5.4 & .021 \\
\hline Delirium $^{a}$ & 433/1090 (40\%) & $3183 / 10,141$ (31\%) & 31.3 & $<.001$ \\
\hline Complete relief $^{\mathrm{b}}$ & 72/433 (17\%) & 482/3183 (15\%) & 0.6 & .42 \\
\hline Respiratory secretions ${ }^{a}$ & $631 / 1357$ (47\%) & 7098/12,397 (57\%) & 57.5 & $<.001$ \\
\hline Complete relief $^{b}$ & $223 / 631(35 \%)$ & 2222/7098 (31\%) & 4.4 & .037 \\
\hline Nausea $^{a}$ & 100/1022 (10\%) & $1472 / 10,214(14 \%)$ & 16.5 & $<.001$ \\
\hline Complete relief & $40 / 100(40 \%)$ & $678 / 1472(46 \%)$ & 1.4 & .24 \\
\hline Pain $^{\mathrm{a}}$ & 786/1283 (61\%) & 7996/11,934 (67\%) & 17.1 & $<.001$ \\
\hline Complete relief ${ }^{b}$ & $538 / 786(68 \%)$ & 5153/7996 (64\%) & 5.0 & .025 \\
\hline PRN opioid against pain ${ }^{a}$ & 1374/1458 (94\%) & 11,793/12,933 (91\%) & 15.7 & $<.001$ \\
\hline PRN drug against anxiety ${ }^{\mathrm{a}}$ & 1340/1453 (92\%) & $11,355 / 12,867(88 \%)$ & 20.5 & $<.001$ \\
\hline PRN drug against nausea ${ }^{a}$ & 1122/1436 (78\%) & $9803 / 12,738$ (77\%) & 1.0 & .32 \\
\hline PRN drug against respiratory secretions ${ }^{a}$ & $1258 / 1448(87 \%)$ & $11,060 / 12,863(86 \%)$ & 0.9 & .35 \\
\hline Close friend(s) and/or relative(s) present with or without staff at the time of death ${ }^{a}$ & $366 / 1419(26 \%)$ & $7114 / 12,736(56 \%)$ & 463 & $<.001$ \\
\hline Someone present at the time of death ${ }^{\mathrm{a}}$ & $805 / 1419(57 \%)$ & $9776 / 12,736(77 \%)$ & 271 & $<.001$ \\
\hline Parenteral fluids/nutrition or enteral-tube feeding given during the last $24 \mathrm{~h}^{\mathrm{a}}$ & $535 / 1433(37 \%)$ & $4406 / 12,782(35 \%)$ & 4.7 & .031 \\
\hline
\end{tabular}

a"Don't know" was an optional answer for the questions on symptom occurrence, and these responses were excluded from the analysis (for breathlessness $n=152$, anxiety $n=287$, delirium $n=386$, respiratory secretions $n=119$, nausea $n=454$, pain $n=193$ in the COVID-19 group and for breathlessness $n=1478$, anxiety $n=2641$, delirium $n=3017$, respiratory secretions $n=761$, nausea $n=2944$, pain $n=1224$ in the reference cohort). Therefore, numbers do not sum to group totals

bAlternatives for answers on symptom relief were "Completely", "Partially" and "Not at all"

'The difference in mean age was calculated with t-test

Abbreviation: $P R N=$ as needed.

injectable PRN opioids against pain $\left(\mathrm{X}^{2}(\mathrm{df}=1, n=14\right.$, $391)=15.7, p<.001)$ and PRN drugs against anxiety $\left(\chi^{2}\right.$ $(\mathrm{df}=1, n=14,320)=20.5, p<.001)$ were more common in the COVID-19 group, although the proportion of prescriptions was high also in the reference cohort. The prescriptions of PRN drugs against nausea and respiratory secretions did not differ between the groups (Table 1).

\section{Differences in symptom occurrence within the COVID-19 group}

\section{Chi-2 analyses and univariate logistic regression}

In the chi- 2 analysis, women more often had anxiety ( $x^{2}$ $(\mathrm{df}=1, n=1189)=4.7, p=.029)$ and nausea $\left(\mathrm{X}^{2}(\mathrm{df}=1\right.$, $n=1022)=7.6, p=.006)$ compared to men, and men more often had respiratory secretions $\left(\mathrm{x}^{2}(\mathrm{df}=1, n=\right.$ $1357)=13.3, p<.001)$, within the COVID-19 group
(Table 2). Occurrence of breathlessness, delirium and pain did not differ between men and women (Table 2).

The occurrence of breathlessness was higher in the age groups of $65-74(75 \%, \mathrm{OR}=2.69,95 \% \mathrm{CI}=1.54-$ $4.71, p=.001), 75-84 \quad(76 \%, \mathrm{OR}=2.82,95 \% \mathrm{CI}=1.72-$ $4.62, p<.001)$ and $85-94$ years $(70 \%, \mathrm{OR}=2.05,95 \%$ $\mathrm{CI}=1.26-3.34, p=.004)$ compared to the oldest $(\geq 95$ years, occurrence $53 \%$ ) in the univariate logistic regression model. There were no age differences seen in occurrence of anxiety, delirium, respiratory secretions, nausea or pain (Table 3).

In the chi- 2 analysis, patients with dementia were more often reported to have suffered from delirium $\left(\chi^{2}\right.$ $(\mathrm{df}=1, n=1090)=10.7, p=.001)$, and less often from anxiety $\left(\mathrm{x}^{2}(\mathrm{df}=1, n=1189)=4.6, p=.033\right)$ and respiratory secretions $\left(\chi^{2}(\mathrm{df}=1, n=1357)=4.0, p=.044\right)$ compared to those without dementia (Table 4). These 
Table 2 Sex differences within the COVID-19 group, not adjusted for age. Analysed with chi-2 test

\begin{tabular}{|c|c|c|c|c|}
\hline Characteristics & Women & Men & $x^{2}$ & $P$-value \\
\hline Breathlessness occurrence $^{a}$ & $403 / 555(73 \%)$ & $550 / 769(72 \%)$ & 0.2 & .66 \\
\hline Breathlessness relief ${ }^{\mathrm{b}}$ & 130/403 (32\%) & 156/550 (28\%) & 1.7 & .20 \\
\hline Anxiety occurrence ${ }^{a}$ & $371 / 510(73 \%)$ & $454 / 679(67 \%)$ & 4.7 & .029 \\
\hline Anxiety relief ${ }^{b}$ & 225/371 (61\%) & 268/454 (59\%) & 0.2 & .64 \\
\hline Delirium occurrence $^{a}$ & 176/455 (39\%) & $257 / 635(41 \%)$ & 0.4 & .55 \\
\hline Delirium relief ${ }^{b}$ & 27/176 (15\%) & 45/257 (18\%) & 0.4 & .55 \\
\hline Respiratory secretions occurrence ${ }^{a}$ & $232 / 570(41 \%)$ & $399 / 787(51 \%)$ & 13.3 & $<.001$ \\
\hline Respiratory secretions relief ${ }^{b}$ & $82 / 232(35 \%)$ & $141 / 399(35 \%)$ & 0.00 & .999 \\
\hline Nausea occurrence ${ }^{a}$ & $55 / 430(13 \%)$ & 45/592 (8\%) & 7.6 & .006 \\
\hline Nausea relief ${ }^{\mathrm{b}}$ & $21 / 55(38 \%)$ & $19 / 45(42 \%)$ & 0.2 & .68 \\
\hline Pain occurrence $^{a}$ & $345 / 548(63 \%)$ & $441 / 735(60 \%)$ & 1.2 & .28 \\
\hline Pain relief ${ }^{\mathrm{b}}$ & $236 / 345$ (68\%) & $302 / 441$ (69\%) & 0.001 & .98 \\
\hline Close friend(s) and/or relative(s) present with or without staff at the time of death ${ }^{a}$ & 149/598 (25\%) & $217 / 821(26 \%)$ & 0.4 & .52 \\
\hline Someone present at the time of death ${ }^{a}$ & $330 / 598(55 \%)$ & $475 / 821(58 \%)$ & 1.0 & .32 \\
\hline Parenteral fluids/nutrition or enteral-tube feeding given during the last 24 hours & $211 / 606(35 \%)$ & $324 / 827$ (39\%) & 2.8 & .092 \\
\hline
\end{tabular}

a"Don't know" was an optional answer for the questions on symptom occurrence, and these responses were excluded from the analysis. Therefore, numbers do not sum to group totals

${ }^{\text {b }}$ Alternatives for answers on symptom relief were "Completely", "Partially" and "Not at all"

findings were confirmed in the multivariate regression model adjusting for age and sex (data not shown).

\section{Multivariate analyses}

The sex differences seen in the chi- 2 analysis regarding anxiety, nauseas and respiratory secretions remained in the multivariate logistic regression model adjusting for age categories (Table 5) and in the multivariate logistic regression model adjusting for both age categories and dementia (data not shown).

Occurrence of breathlessness was higher in the age groups of 65-74, 75-84 and 85-94 years compared to the oldest ( $\geq 95$ years) in the multivariate logistic regression models adjusting for sex (Table 5), and adjusting for sex and dementia (data not shown). No other significant age differences regarding symptom occurrence were seen in these multivariate models.

\section{Differences in symptom relief within the COVID-19 group}

There were no sex differences regarding relief of symptoms when present (Table 2). In univariate logistic regression using age as a continuous variable, relief of the following symptoms was more likely with increasing age: breathlessness $(\mathrm{OR}=1.03,95 \% \mathrm{CI}=1.01-1.04, p=.002)$, anxiety $(\mathrm{OR}=1.03,95 \% \mathrm{CI}=1.01-1.04, p=.001)$ and pain $(\mathrm{OR}=1.02,95 \% \mathrm{CI}=1.002-1.034, p=.026)$. These differences remained significant after adjusting for sex. Relief of delirium, respiratory secretions and nausea did not differ with age.
Differences regarding someone present at time of death and parenteral fluids within the COVID-19 group No sex differences were seen regarding the proportion of patients who died alone, the proportion of patients who had close friend(s) and/or relative(s) present at the time of death, or whether parenteral fluids/nutrition or enteral-tube feeding were administered during the last $24 \mathrm{~h}$ (Table 2). Furthermore, these outcomes did not differ between the groups with and without dementia within the COVID-19 group (Table 4).

Patients in the age group 65-74 years more often had close friend(s) and/or relative(s) present at the time of death compared to the oldest $(\mathrm{OR}=1.96,95 \% \mathrm{CI}=1.07$ $3.61, p=.030)$. The two youngest groups of $18-64(\mathrm{OR}=$ 2.62, 95\% CI $=1.33-.5 .16, p=.006)$ and $65-74(\mathrm{OR}=$ $1.95,95 \% \mathrm{CI}=1.15-3.30,=.013)$ years were more likely to die with someone, that is, staff and/or close friend(s)/ relative(s), present, compared to the oldest. The three youngest age groups, $18-64(\mathrm{OR}=3.06,95 \% \mathrm{CI}=1.55-$ 6.02, $p=.001), 65-74(\mathrm{OR}=2.32,95 \% \mathrm{CI}=1.32-4.08$, $p=.003)$ and $75-84$ years $(\mathrm{OR}=1.75,95 \% \mathrm{CI}=1.04-$ 2.94, $p=.034$ ), were more likely to receive parenteral fluids/nutrition or enteral-tube feeding during the last $24 \mathrm{~h}$ compared to the group 95 years and older (Table 3). These differences remained when adjusting for sex, and when adjusting for sex and a diagnosis of dementia (data not shown).

\section{Discussion}

In this national register study on 1476 COVID-19related deaths during the first pandemic wave at 
Table 3 Age differences within the COVID-19 group, not adjusted for sex. Analysed with logistic regression

\begin{tabular}{|c|c|c|c|c|c|}
\hline Characteristics & Age, years & Number of patients & OR & $95 \% \mathrm{Cl}$ & $p$ value \\
\hline \multirow[t]{5}{*}{ Breathlessness occurrence $^{a}$} & $18-64$ & $42 / 63(67 \%)$ & 1.76 & $.88-3.50$ & .11 \\
\hline & $65-74$ & 138/183 (75\%) & 2.69 & $1.54-4.71$ & .001 \\
\hline & $75-84$ & 379/497 (76\%) & 2.82 & $1.72-4.62$ & $<.001$ \\
\hline & 85-94 & 353/504 (70\%) & 2.05 & $1.26-3.34$ & .004 \\
\hline & $\geq 95$ & $41 / 77(53 \%)$ & Ref & & \\
\hline \multirow[t]{5}{*}{ Anxiety occurrence ${ }^{a}$} & $18-64$ & 40/54 (74\%) & 1.60 & $.75-3.44$ & .23 \\
\hline & $65-74$ & 106/148 (72\%) & 1.41 & $.79-2.54$ & .25 \\
\hline & $75-84$ & $319 / 456$ (70\%) & 1.30 & $.79-2.16$ & .30 \\
\hline & $85-94$ & $310 / 453(68 \%)$ & 1.21 & $.73-2.01$ & .45 \\
\hline & $\geq 95$ & $50 / 78(64 \%)$ & Ref & & \\
\hline \multirow[t]{5}{*}{ Delirium occurrence ${ }^{a}$} & $18-64$ & $13 / 48(27 \%)$ & .65 & $.29-1.46$ & .30 \\
\hline & $65-74$ & $53 / 149(36 \%)$ & .97 & $.53-1.77$ & .91 \\
\hline & $75-84$ & $165 / 408(40 \%)$ & 1.19 & $.69-2.04$ & .53 \\
\hline & $85-94$ & 178/419 (43\%) & 1.29 & $.76-2.21$ & .35 \\
\hline & $\geq 95$ & $24 / 66(36 \%)$ & Ref & & \\
\hline \multirow[t]{5}{*}{ Respiratory secretions occurrence ${ }^{a}$} & $18-64$ & $22 / 62(36 \%)$ & .61 & $.31-1.19$ & .15 \\
\hline & $65-74$ & $83 / 185(45 \%)$ & .90 & $.53-1.51$ & .68 \\
\hline & $75-84$ & 231/511 (45\%) & .91 & $.57-1.45$ & .69 \\
\hline & $85-94$ & $256 / 517(50 \%)$ & 1.08 & $.68-1.72$ & .74 \\
\hline & $\geq 95$ & 39/82 (48\%) & Ref & & \\
\hline \multirow[t]{5}{*}{ Nausea occurrence ${ }^{a}$} & $18-64$ & 6/43 (14\%) & 1.46 & $.44-4.88$ & .54 \\
\hline & $65-74$ & 19/135 (14\%) & 1.47 & $.56-3.90$ & .43 \\
\hline & $75-84$ & 39/378 (10\%) & 1.04 & $.42-2.56$ & .94 \\
\hline & $85-94$ & 30/406 (7\%) & .72 & $.29-1.81$ & .48 \\
\hline & $\geq 95$ & $6 / 60(10 \%)$ & Ref & & \\
\hline \multirow[t]{5}{*}{ Pain occurrence ${ }^{a}$} & $18-64$ & $34 / 64$ (53\%) & .71 & $.36-1.38$ & .31 \\
\hline & $65-74$ & $112 / 172(65 \%)$ & 1.17 & $.67-2.03$ & .59 \\
\hline & $75-84$ & $296 / 479(62 \%)$ & 1.01 & $.62-1.65$ & .97 \\
\hline & $85-94$ & $296 / 490(60 \%)$ & .95 & $.58-1.56$ & .85 \\
\hline & $\geq 95$ & $48 / 78(62 \%)$ & Ref & & \\
\hline \multirow[t]{5}{*}{ Close friend(s) and/or relative(s) present with or without staff at the time of death ${ }^{\mathrm{a}}$} & $18-64$ & $20 / 71(28 \%)$ & 1.43 & $.68-3.01$ & .35 \\
\hline & $65-74$ & $71 / 203(35 \%)$ & 1.96 & $1.07-3.61$ & .030 \\
\hline & $75-84$ & $150 / 537(28 \%)$ & 1.41 & $.80-2.50$ & .23 \\
\hline & $85-94$ & $108 / 529(20 \%)$ & .94 & $.53-1.67$ & .82 \\
\hline & $\geq 95$ & $17 / 79(22 \%)$ & Ref & & \\
\hline \multirow[t]{5}{*}{ Someone present at the time of death ${ }^{\mathrm{a}}$} & $18-64$ & $51 / 71(72 \%)$ & 2.62 & $1.33-.5 .16$ & .006 \\
\hline & $65-74$ & 133/203 (66\%) & 1.95 & $1.15-3.30$ & .013 \\
\hline & $75-84$ & 312/537 (58\%) & 1.42 & $.89-2.28$ & .15 \\
\hline & $85-94$ & $270 / 529(51 \%)$ & 1.07 & $.67-1.72$ & .78 \\
\hline & $\geq 95$ & $39 / 79(49 \%)$ & Ref & & \\
\hline \multirow[t]{5}{*}{ Parenteral fluids/nutrition or enteral-tube feeding given during the last 24 hours $^{\mathrm{a}}$} & $18-64$ & $37 / 70(53 \%)$ & 3.06 & $1.55-6.02$ & .001 \\
\hline & $65-74$ & $92 / 200(46 \%)$ & 2.32 & $1.32-4.08$ & .003 \\
\hline & $75-84$ & $213 / 545(39 \%)$ & 1.75 & $1.04-2.94$ & .034 \\
\hline & $85-94$ & $171 / 536(32 \%)$ & 1.28 & $.76-2.15$ & .36 \\
\hline & $\geq 95$ & 22/82 (27\%) & Ref & & \\
\hline
\end{tabular}


hospitals we found that breathlessness, anxiety and delirium were more common, while respiratory secretions, nausea and pain were less frequently seen during the last week in life compared to a reference cohort. When present, complete relief of anxiety, pain and respiratory secretions was more often achieved compared to the pre-pandemic population of dying patients in hospital. Several palliative care manuals for treating symptoms in patients with COVID-19 did foresee that respiratory secretions could be a common symptom and suggested treatment with antimuscarinic drugs [19-21].

We also found that a higher proportion of patients dying in hospitals due to COVID-19 died alone. The presence of next of kin was less common, and staff were not able to fully compensate for their absence, which was also seen in other countries [22]. This was probably due to lack of personal protective equipment as well as a general strain on healthcare personnel resources. Another possible explanation could be the difficulty of prognosticating dying and death in a new disease.

Younger patients in the COVID-19 group more often had someone present at the time of death. Since the SRPC data do not contain information about who received intensive care, we cannot say to what extent the level of care covariates with these results, but it is probable that patients who died in intensive care units had staff present to a much higher extent.

Interestingly, the proportion of people with dementia dying in hospitals did not differ between the COVID-19 group and the reference cohort. There has been a debate in Sweden regarding whether older people with multiple diseases, including dementia, residing in nursing homes were offered appropriate care for COVID-19 [23]. Our findings indicate that access to hospital care for people with dementia was similar to the access before the pandemic.

Within the group of patients dying from COVID-19 in hospitals, breathlessness was more common among younger patients. Furthermore, patients with dementia were more often reported to have suffered from delirium, and less often from anxiety and respiratory secretions compared to those without dementia. This is consistent with the findings by Martín-Sánchez et al. that described old age as a predictive factor for fewer respiratory and more unspecific symptoms from COVID19 [24], and the findings by Poloni et al. that the combination of COVID-19 and dementia was associated with delirium [15]. In a recent study by our group, we showed that nursing home residents who died in hospital with COVID-19 were younger and also more often suffered from breathlessness and delirium during end of life compared to those who died with COVID-19 in their nursing home [25].

Furthermore, we also found that women who died from COVID-19 more often had anxiety and nausea the last week before death, while men more often suffered from respiratory secretions. While other studies also have found a symptom difference between women and men in mild to moderate COVID-19 [26, 27], it was somewhat surprising to find such measurable differences also for patients hospitalised for and subsequently deceased from COVID-19, after adjusting for age.

During the COVID-19 pandemic, assessment of prognosis and choice of whether invasive and potentially distressing treatments, such as mechanical ventilation, should be given or not, is especially demanding [28]. A person might be in a palliative stage, for example, due to a metastatic cancer disease with limited survival prospects in the long run. Still, the same person might have realistic chances to recover from COVID-19, which makes decisions more complicated in the face of a new disease with partly unknown trajectory, at least in the individual case [29]. However, in this study, we only selected patients whose death, according to hospital staff, was expected and foreseeable. Therefore, symptom control and comfort should have been main priorities.

Table 4 Differences between patients with and without dementia in the COVID-19 group, not adjusted for sex or age. Analysed with chi-2 test

\begin{tabular}{|c|c|c|c|c|}
\hline Characteristics & Dementia & No dementia & $x^{2}$ & $P$-value \\
\hline Breathlessness occurrence ${ }^{a}$ & $60 / 93(65 \%)$ & $893 / 1231(73 \%)$ & 2.8 & .097 \\
\hline Anxiety occurrence ${ }^{a}$ & $47 / 80(59 \%)$ & 778/1109 (70\%) & 4.6 & .033 \\
\hline Delirium occurrence ${ }^{a}$ & $47 / 83(57 \%)$ & 386/1007 (38\%) & 10.7 & .001 \\
\hline Respiratory secretions occurrence ${ }^{a}$ & 36/98 (37\%) & $595 / 1259$ (47\%) & 4.0 & .044 \\
\hline Nausea occurrence ${ }^{a}$ & $6 / 80(8 \%)$ & $94 / 942(10 \%)$ & 0.5 & .47 \\
\hline Pain occurrence $e^{a}$ & 59/92 (64\%) & 727/1191 (61\%) & 0.3 & .56 \\
\hline Close friend(s) and/or relative(s) present with or without staff at the time of death ${ }^{a}$ & 23/99 (23\%) & $343 / 1320(26 \%)$ & 0.4 & .55 \\
\hline Someone present at the time of death ${ }^{a}$ & $49 / 99(50 \%)$ & $756 / 1320(57 \%)$ & 2.3 & .13 \\
\hline Parenteral fluids/nutrition or enteral-tube feeding given during the last 24 hours $^{\mathrm{a}}$ & $31 / 100(31 \%)$ & $504 / 1333(38 \%)$ & 1.8 & .18 \\
\hline
\end{tabular}

a"Don't know" was an optional answer for the questions on symptom occurrence, and these responses were excluded from the analysis. Therefore, numbers do not sum to group totals 
Table 5 Sex differences (ref: women) in symptom occurrence in the COVID-19 group, adjusted for age categories (ref: oldest). Analysed with logistic regression

\begin{tabular}{|c|c|c|c|c|c|c|c|}
\hline \multirow[t]{2}{*}{ Characteristics } & \multicolumn{3}{|c|}{ Sex differences (ref: women) } & \multicolumn{4}{|c|}{ Age categories (ref: oldest) } \\
\hline & OR & $95 \% \mathrm{Cl}$ & $p$ value & Age, years & OR & $95 \% \mathrm{Cl}$ & $P$-value \\
\hline \multirow[t]{5}{*}{ Breathlessness occurrence $^{a}$} & .91 & $.71-1.16$ & .43 & $18-64$ & 1.78 & $.89-3.54$ & .10 \\
\hline & & & & $65-74$ & 2.76 & $1.57-4.86$ & $<.001$ \\
\hline & & & & $75-84$ & 2.85 & $1.74-4.68$ & $<.001$ \\
\hline & & & & $85-94$ & 2.07 & $1.27-3.37$ & .003 \\
\hline & & & & $\geq 95$ & Ref & & \\
\hline \multirow[t]{5}{*}{ Anxiety occurrence ${ }^{a}$} & .74 & $.57-.96$ & .020 & $18-64$ & 1.66 & $.77-3.58$ & .20 \\
\hline & & & & $65-74$ & 1.52 & $.84-2.73$ & .17 \\
\hline & & & & $75-84$ & 1.34 & $.81-2.23$ & .25 \\
\hline & & & & $85-94$ & 1.24 & $.75-2.06$ & .40 \\
\hline & & & & $\geq 95$ & Ref & & \\
\hline \multirow[t]{5}{*}{ Delirium occurrence ${ }^{a}$} & 1.11 & $.86-1.42$ & .43 & $18-64$ & .64 & $.28-1.44$ & .28 \\
\hline & & & & $65-74$ & .94 & $.51-1.73$ & .85 \\
\hline & & & & $75-84$ & 1.18 & $.69-2.02$ & .56 \\
\hline & & & & $85-94$ & 1.29 & $.75-2.20$ & .37 \\
\hline & & & & $\geq 95$ & Ref & & \\
\hline \multirow[t]{5}{*}{ Respiratory secretions occurrence ${ }^{a}$} & 1.53 & $1.23-1.90$ & $<.001$ & $18-64$ & .57 & $.30-1.13$ & .11 \\
\hline & & & & $65-74$ & .80 & $.47-1.35$ & .40 \\
\hline & & & & $75-84$ & .86 & $.53-1.37$ & .52 \\
\hline & & & & $85-94$ & 1.03 & $.64-1.65$ & .90 \\
\hline & & & & $\geq 95$ & Ref & & \\
\hline \multirow[t]{5}{*}{ Nausea occurrence ${ }^{a}$} & .52 & $.34-.80$ & .003 & $18-64$ & 1.68 & $.50-5.68$ & .40 \\
\hline & & & & $65-74$ & 1.74 & $.65-4.67$ & .27 \\
\hline & & & & $75-84$ & 1.11 & $.45-2.75$ & .83 \\
\hline & & & & $85-94$ & .76 & $.30-1.91$ & .56 \\
\hline & & & & $\geq 95$ & Ref & & \\
\hline \multirow[t]{5}{*}{ Pain occurrence ${ }^{a}$} & .87 & $.69-1.10$ & .24 & $18-64$ & .72 & $.37-1.41$ & .34 \\
\hline & & & & $65-74$ & 1.20 & $.69-2.10$ & .52 \\
\hline & & & & $75-84$ & 1.03 & $.63-1.68$ & .92 \\
\hline & & & & $85-94$ & .97 & $.59-1.58$ & .89 \\
\hline & & & & $\geq 95$ & Ref & & \\
\hline
\end{tabular}

a"Don't know" was an optional answer for the questions on symptom occurrence, and these responses were excluded from the analysis. Therefore, numbers do not sum to group totals

Intravenous fluids administered during the last days of life may lead to complications such as pulmonary oedema and increased breathlessness [30]. Discontinuation of intravenous fluids such as artificial hydration and nutrition is generally recommended near end of life [1]. Slightly more patients dying from COVID-19 were prescribed parenteral administration of fluids and/or nasogastric feeding (37\%) compared to patients dying in hospitals during 2019 (35\%). This can possibly reflect prognostic uncertainty for COVID-19 and is perhaps also a product of the debate in Sweden during spring
2020 on whether elderly people with multiple diseases received appropriate care for COVID-19.

\section{Strengths and limitations}

This study used data from a Swedish national quality register, the SRPC. The SRPC collects data about endof-life care with an established method and contains data about more than $60 \%$ of all yearly deaths in Sweden since 2012. When the pandemic started, the SRPC added questions about COVID-19 and COVID-19 testing in their web-based end-of-life questionnaire, allowing data 
collection for this patient category early in the pandemic.

During the study period, PCR tests to verify the COVID-19 diagnosis were limited. Therefore, some of the patients included in this study had only a clinical diagnosis. Furthermore, for patients with multiple diseases reported to the SRPC, we cannot determine whether COVID-19 was the underlying or a contributing cause of death. We have not been able to access Swedish official cause of death data, as these are added from the National Board of Health and Welfare to the SRPC with a delay of more than 12 months. However, we have used a definition similar to that of the Public Health Agency (Folkhälsomyndigheten), which reports deaths for people with a reported COVID-19 diagnosis during the last 30 days as a death from COVID-19 [9].

\section{Conclusions}

This national register study shows that although COVID-19 is a new disease with new symptoms and trajectories, the standard medical strategies for end-of-life care in Swedish hospitals seemed to work in an acceptable way during the first wave of the pandemic. Symptoms in COVID-19 deaths in hospitals in 2020 were relieved to a similar or even a higher degree than in hospitals in 2019.

Importantly, though, when the hospitals were closed to relatives and visitors, patients dying from COVID-19 more frequently died alone, and healthcare providers were not able to substitute for absent relatives.

\section{Abbreviations}

df: Degree of freedom; ELQ: End-of-life questionnaire; COVID-19: Coronavirus disease 2019; SRPC: Swedish Register of Palliative Care; PRN: Pro re nata (as needed); PCR: Polymerase chain reaction; OR: Odds ratio; Cl: Confidence interval

\section{Authors' contributions}

All authors together planned the study. SL and LM retrieved the data set. LM and JB performed the statistical analysis, and all authors together interpreted the results. JB and $L M$ wrote the first manuscript draft, and $P S, J B, C H$ and $S L$ made critical revisions. All authors approved the final version. All authors meet criteria for authorship.

\section{Funding}

This study was funded by the Swedish Register of Palliative Care, Region Västerbotten, Region Stockholm (ALF project 20200472) and Stockholms Sjukhem Foundation's Jubilee Fund. The funders had no role regarding study design, collection, analysis, or interpretation of data or in writing the manuscript. Open Access funding provided by Umea University.

\section{Availability of data and materials}

The dataset contains personally identifying information, such as personal identity numbers, and potentially identifying information, such as date of death, and therefore is subject to ethical and legal restrictions on public sharing. We cannot share the dataset, which is on an individual level, because it is not permitted according to the laws that apply in Sweden.

\section{Declarations}

Ethics approval and consent to participate

Patients included in the study were deceased and had already been registered in the Swedish Register of Palliative Care by the nurse or physician responsible for the patient. The study was approved by the SRPC management group on 12 November 2020. The working procedure and study design were examined by the Ethical Review Board in Sweden, who had no ethical objections to the study (registration number 2020-02186). The official national ethical review board gave permission to use the information about the deceased and healthcare data, and required no informed consent from next of kin, in accordance with Swedish law.

\section{Consent for publication}

Not applicable.

\section{Competing interests}

The authors declare no competing interests.

\section{Author details}

1Department of Radiation Sciences, Umeå University, SE-90187 Umeå, Sweden. ${ }^{2}$ Palliative Care Unit, Stockholms Sjukhem Foundation, Stockholm, Sweden. ${ }^{3}$ R \& D Department, Stockholms Sjukhem Foundation, Stockholm, Sweden. ${ }^{4}$ Department of Molecular Medicine and Surgery, Karolinska Institutet, Stockholm, Sweden. ${ }^{5}$ Department of Oncology-Pathology, Karolinska Institutet, Stockholm, Sweden.

Received: 31 March 2021 Accepted: 2 June 2021

Published online: 01 July 2021

\section{References}

1. Mottiar M, Hendin A, Fischer L, Roze des Ordons A, Hartwick M. End-of-life care in patients with a highly transmissible respiratory virus: implications for COVID-19. Can J Anaesth. 2020;67:1417.

2. Lake MA. What we know so far: COVID-19 current clinical knowledge and research. Clin Med (Lond). 2020;20(2):124-7.

3. Spiteri G, Fielding J, Diercke M, Campese C, Enouf V, Gaymard A, et al. First cases of coronavirus disease 2019 (COVID-19) in the WHO European Region, 24 January to 21 February 2020. Euro Surveill. 2020;25(9):2000178.

4. Keeley P, Buchanan D, Carolan C, Pivodic L, Tavabie S, Noble S. Symptom burden and clinical profile of COVID-19 deaths: a rapid systematic review and evidence summary. BMJ Support Palliat Care. 2020;10:381.

5. Sese D, Makhoul A, Hoeksema L, Shoemaker $L$. The role of palliative care in COVID-19. Cleve Clin J Med. 2020. Epub ahead of print. PMID: 32471812

6. Fusi-Schmidhauser T, Preston NJ, Keller N, Gamondi C. Conservative management of COVID-19 patients - emergency palliative care in action. J Pain Symptom Manag. 2020;60:e27.

7. Thomas JD, Leiter RE, Abrahm JL, Shameklis JC, Kiser SB, Gelfand SL, et al. Development of a palliative care toolkit for the COVID-19 pandemic. J Pain Symptom Manag. 2020;60:e22.

8. Ferguson L, Barham D. Palliative care pandemic pack: a specialist palliative care service response to planning the COVID-19 pandemic. J Pain Symptom Manag. 2020;60:e18.

9. FHM. Information on data sources (in Swedish: Information om datakällor) From: Confirmed cases in Sweden (in Swedish: Bekräftade fall i Sverige). Public Health Agency of Sweden (Folkhälsomyndigheten). $2020 \mathrm{https}$ :// www.folkhalsomyndigheten.se/smittskydd-beredskap/utbrott/aktuellautbrott/covid-19/statistik-och-anMalyser/bekraftade-fall-i-sverige. Accessed 8 Mar 2021.

10. Iftimie S, López-Azcona AF, Vallverdú I, Hernández-Flix S, de Febrer G, Parra $\mathrm{S}$, et al. First and second waves of coronavirus disease-19: a comparative study in hospitalized patients in Reus, Spain. PLoS One. 2021;16(3):e0248029.

11. Tabah A, Ramanan M, Laupland KB, Buetti N, Cortegiani A, Mellinghoff J, et al. Personal protective equipment and intensive care unit healthcare worker safety in the COVID-19 era (PPE-SAFE): An international survey. J Crit Care. 2020;59:70-5. https://doi.org/10.1016/j.jcrc.2020.06.005 Epub 2020 Jun 13. Erratum in: J Crit Care. 2021 Jun;63:280-281.

12. Martinsson L, Strang P, Bergström J, Lundström S. Were clinical routines for good end-of-life care maintained in hospitals and nursing homes during the first three months of the outbreak of COVID-19? A national register study. J Pain Symptom Manag. 2021;61(1):e11-9. 
13. Strang P, Bergström J, Martinsson L, Lundström S. Dying from COVID-19: loneliness, end-of-life discussions, and support for patients and their families in nursing homes and hospitals. A national register study. J Pain Symptom Manag. 2020;60(4):e2-e13.

14. Cook DJ, Takaoka A, Hoad N, Swinton M, Clarke FJ, Rudkowski JC, et al. Clinician perspectives on caring for dying patients during the pandemic : a mixed-methods study. Ann Intern Med. 2021;174(4):493-500.

15. Poloni TE, Carlos AF, Cairati M, Cutaia C, Medici V, Marelli E, et al. Prevalence and prognostic value of delirium as the initial presentation of COVID-19 in the elderly with dementia: an Italian retrospective study. EClinicalMedicine. 2020:26:100490.

16. Martinsson L, Strang P, Bergström J, Lundström S. Dying from COVID-19 in nursing homes-sex differences in symptom occurrence. BMC Geriatr. 2021; 21(1):294.

17. Martinsson L, Heedman PA, Lundström S, Axelsson B. Improved data validity in the Swedish register of palliative care. PLoS One. 2017;12(10):e0186804.

18. Martinsson L, Heedman PA, Lundström S, Fransson G, Axelsson B. Validation study of an end-of-life questionnaire from the Swedish register of palliative care. Acta Oncol. 2011;50(5):642-7.

19. The BC Centre for Palliative Care. Symptom management guideline for end of life care of people with COVID-19 - March 2020. Available from: https:// bc-cpc.ca/cpc/publications/symptom-management-guidelines/symptom-ma nagement-guidelines-printable/.

20. Chidiac C, Feuer D, Naismith J, Flatley M, Preston N. Emergency palliative care planning and support in a COVID-19 pandemic. J Palliat Med. 2020; 23(6):752-3.

21. National Board of Health and Welfare. Symtomlindring i livets slutskede Läkemedelsbehandling i palliativ vård vid covid-19 [Symptom alleviation during end of life - Pharmacological treatment in palliative care for COVID19]. Socialstyrelsen 2020 .

22. Anderson-Shaw LK, Zar FA. COVID-19, moral conflict, distress, and dying alone. J Bioeth Inq. 2020;17(4):777-82.

23. Amér $\mathrm{S}$, Molnar $\mathrm{C}$, Tuutma $\mathrm{M}$, Metzner $\mathrm{C}$, Tegman $\mathrm{P}$, Taranger $\mathrm{M}$, et al. Almost two-thirds of the elderly with COVID-19 surviving in nursing homes. Lakartidningen. 2020;117:20104.

24. Martín-Sánchez FJ, Del Toro E, Cardassay E, Valls Carbó A, Cuesta F, Vigara $\mathrm{M}$, et al. Clinical presentation and outcome across age categories among patients with COVID-19 admitted to a Spanish emergency department. Eur Geriatr Med. 2020;11(5):829-41.

25. Strang P, Martinsson L, Bergström J, Lundström S. COVID-19: symptoms in dying residents of nursing homes and in those admitted to hospitals. J Palliat Med. 2021;24(7):1067-71.

26. Lechien JR, Chiesa-Estomba CM, De Siati DR, Horoi M, Le Bon SD, Rodriguez $A$, et al. Olfactory and gustatory dysfunctions as a clinical presentation of mild-to-moderate forms of the coronavirus disease (COVID-19): a multicenter European study. Eur Arch Otorhinolaryngol. 2020;277(8):225161.

27. Biadsee A, Biadsee A, Kassem F, Dagan O, Masarwa S, Ormianer Z. Olfactory and oral manifestations of COVID-19: sex-related symptoms - a potential pathway to early diagnosis. Otolaryngol Head Neck Surg. 2020;163:722.

28. Fadul N, Elsayem AF, Bruera E. Integration of palliative care into COVID-19 pandemic planning. BMJ Support Palliat Care. 2021;11(1):40-4.

29. Lièvre A, Turpin A, Ray-Coquard I, Le Malicot K, Thariat J, Ahle G, et al. Risk factors for coronavirus disease 2019 (COVID-19) severity and mortality among solid cancer patients and impact of the disease on anticancer treatment: a French nationwide cohort study (GCO-002 CACOVID-19). Eur J Cancer. 2020;141:62-81.

30. Fritzson A, Tavelin B, Axelsson B. Association between parenteral fluids and symptoms in hospital end-of-life care: an observational study of 280 patients. BMJ Support Palliat Care. 2015;5(2):160-8.

\section{Publisher's Note}

Springer Nature remains neutral with regard to jurisdictional claims in published maps and institutional affiliations.

Ready to submit your research? Choose BMC and benefit from:

- fast, convenient online submission

- thorough peer review by experienced researchers in your field

- rapid publication on acceptance

- support for research data, including large and complex data types

- gold Open Access which fosters wider collaboration and increased citations

- maximum visibility for your research: over $100 \mathrm{M}$ website views per year

At $\mathrm{BMC}$, research is always in progress.

Learn more biomedcentral.com/submissions 